\title{
An EFL In-service Training Program for Developing EFL Teachers' Perofrmance
} Khalid M. Alwahibee

Associate Professor of Curriculum and Instruction of English, Department of English Languages and Translation

\section{Abstract}

This study aimed to investigate the preparation of Saudi high school English language teachers and determine whether they needed in-service training programs or not. A 28-item questionnaire was distributed to all 49 English language teachers in Al-Kharj Province 27 schools in the Kingdom of Saudi Arabia. The results revealed that $64 \%$ of the English teachers were not will prepared by their undergraduate programs to be good English language teachers. The results also revealed that the teachers did not revive enough methodology courses and thus lack content-based knowledge about how to teach language. The study also investigated teachers do not attend in-service programs or workshops for many reasons. Finally, the study presented some suggestions and implications for the development of Saudi English language teachers' skills. Also, it provided some suggestions to the Ministry of Education to review the procedures and requirements for hiring English language teachers. 
An EFL In-service Training Program for Developing EFL

Teachers' Perofrmance

\section{برنامج تدريب على رأس العمل لتطوير أداء معلمي اللغة الإنجليزية كلغة ثانية}

ملخص: هدفت هذه الدراسة للتحقق من إعداد معلمي اللغة الإنجليزية في

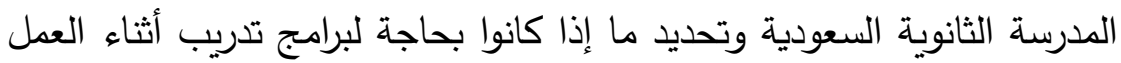

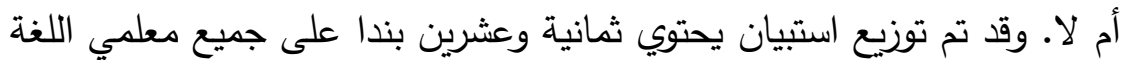

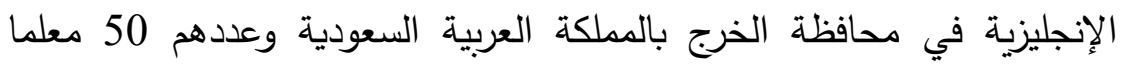
موزعون على 27 مدرسة. وكثفت النتائج أن 64٪ من مدرسي اللغة الإنجليزية لم يكونوا معدين بشكل جيد خلال دراستهم في المرحلة الجامعية ليكونوا معلمين الإني جيدين. وأظهرت النتائج أيضا أن المعلمين لم يحصلوا على مالئ ما يكفي من دورات

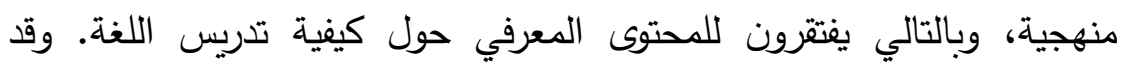
اكتشفت الدراسة أيضا أن هناك أسباب عديدة لعدم حضور المعلمين بالدورات

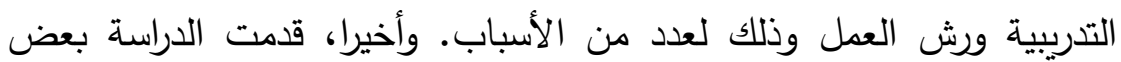
الدقترحات والتطبيقات لتطوير مهارات معلمي اللغة الإنجليزية السعوديين. أيضا، قدمت الدراسة بعض الاقتراحات لوزارة التعليم لكراجعة الإجراءات والمتطلبات لتوظيف معلمي اللغة الإنجليزية. 


\section{An EFL In-service Training Program for Developing EFL Teachers' Perofrmance}

Khalid M. Alwahibee

Associate Professor of Curriculum and Instruction of English, Department of English Languages and Translation

A Survey of the Preparation of English Language Teachers in Selected Secondary Schools in

Al-Kharj Province, Saudi Arabia: The Need for an InService Training Program for Saudi English as a Foreign Language Teachers

One major problem of secondary education in the Kingdom of Saudi Arabia is the students' lack of adequate English language skills, which has led them to score poorly on the English language examinations given to them at the end of every semester.

There are many causes of these weak exam results. As some studies indicate, these causes may include the methods used in teaching English, a lack of good teaching materials, students' lack of interest in learning English, insufficient number of qualified instructors, and finally, weak preparation of English teachers. In addition, students' performances are highly affected by their teachers, who have great influence on the teaching and learning process (Wright, Horn, \& Sanders, 1997). Many studies have attempted to solve this problem, but few have examined the adequacy of pre-service training for English teachers in these schools. Therefore, underlying this study was based on the assumption that for teaching English as a foreign language (EFL) in the Saudi Arabian context, the teachers' competency is a crucial factor in students' producing successful learning outcomes.

The quality of the teachers is reflected in the quality of education. Teachers can continue their professional

$$
\text { مجلة كلية التربية- جامعة عين شمس } 17 \text { () العدد الأربعون (الجزء الرابع) } 2016
$$


education and increase their qualifications through preserve and in-service training (Saban, 2002). Teachers are expected to pass some in-service education and training (INSET) courses to be qualified (Kazemi \& Ashrafi, 2014). Other researchers have indicated that INSET courses will play a major role in solving the obstacles and problems facing the development of teachers (Hmmadou, 2004; Lee, 2007).

This study examined the adequacy of the preparation of EFL teachers in some Al-Kharj Province secondary schools and decide whether that preparation was related to the teachers' instructional practices. This study will also examine the necessity of an in-service training program for English teachers in Saudi schools. For this purpose, a questionnaire is being adapted from Akintola (1982). In Saudi Arabia, not much attention is given to in-service teacher training. Therefore, using Akintola's questionnaire with a few modifications for Saudi teachers will be very helpful. The questionnaire will be distributed to all English language teachers in Al-Kharj province. It will investigate whether English teachers in public schools have been properly trained to teach English. Also, it aims to show the importance and need for continuing in-service training for teachers. It is expected that the results of this study will give full insight into English language teachers in Saudi public schools and whether they need in-service training programs or not.

\section{Statement of the Problem}

As a supervisor for student teachers, I noticed that the student teachers have some problems with demonstrating certain professional teaching practices during their internships. Some of them did not practice what they learned in their methodology and teaching courses. Others were not aware of language teaching strategies. Lack of teaching

$$
\text { مجلة كلية التربية- جامعة عين شمس } 18 \text { () العدد الأربعون (الجزء الرابع) } 2016
$$


skills was the most obvious issue. In addition, most Saudi English teachers claimed that once they graduated from college and were hired as teachers, they never had any type of continued training.

\section{Purpose of the Study}

The main purpose of the study is to show the points of weakness in the preparation of teachers' lie and examine the need for in-service training programs for English teachers.

\section{Significance of the Study}

The significance of the study is to provide suggestions for preparing Saudi English teachers. It will try to give a good model for the in-service training program. Moreover, it will bridge the gap between theory and practice.

\section{Research Questions}

1. Have Saudi English teachers been adequately prepared to teach English in general?

2. Are they adequately prepared to use English language teaching strategies?

3. Are they adequately prepared to deal with English language skills (reading, writing, listening, speaking)?

4. Are they aware of applied linguistics issues?

5. Do Saudi English teachers need an in-service training program?

6. How do schools of education in the United States prepare teachers?

7. How do schools of education in the United States deliver in-service programs for English teachers?

8. Are Saudi English teachers aware of the difference between theory and practice? 
An EFL In-service Training Program for Developing EFL

Teachers' Perofrmance

\section{Literature Review}

\section{First: Saudi English Teachers' Preparation}

For the last two to three decades, most Saudi English language teachers in public schools have been graduates of schools of arts or education with bachelor's degrees in English language and literature (Zaid, 1993). In these colleges, students are taught theory with little training on how to teach. Al Malihi (2015) mentioned that, "EFL teacher's preparation program in the Kingdom of Saudi Arabia can be described as non-systematical and inadequate" (p. 88). She added, "colleges of arts prepare students to be English or English-Arabic translation specialists-not necessarily English teachers" (p. 88). Unfortunately, most of the colleges from which English teachers graduate offer few educational courses, and they do not meet the standards needed to teach EFL (Al-Hazmi, 2003). In most English language programs, university and college requirements dominate study plans. Therefore, English departments cannot add more credits and courses to meet the actual number of credits needed for the internship. In his book, Alseghayer (2011) indicates that only $10 \%$ of the programs constitute teaching method courses. He indicated that, "the current programs are inadequate with regard to disciplinary knowledge, pedagogical content knowledge, and technological pedagogical knowledge" (p. 22).

The preparation of English language graduates varies from college to college in the Kingdom of Saudi Arabia. As stated in the introduction, weak students are the result of weak teachers. The inverse is also true according to Rice (2003), who mentioned that good teachers produce good students. The existence of an excellent Saudi English language teacher cannot be attributed to the teacher's college background. Rather, it is related to the teacher's decision to

$$
\text { مجلة كلية التربية- جامعة عين شنمس } 20 \text { () العدد الأربعون (الجزء الرابع) } 2016
$$


improve and develop skills and gain experience overtime. Thus, this paper suggests that until universities and colleges, which prepare student teachers, reevaluate their programs, the Ministry of Education should work on an in-service education and training program for its teachers in public schools, particularly at the secondary level.

In conclusion, preservice English language teaching programs in Saudi Arabia are not adequately qualified to cope with teaching and educational changes. Since most preservice English language teaching programs are a mix between teaching students English as a subject and training them to be teachers in the future, which is a worldwide phenomenon, great emphasis is placed on English courses for subjects such as linguistics and literature (Freeman, 2001). Many researchers, such as Freeman (1989), Johnson (2000), and Richards (1998) have concluded that student teachers may not teach English very well because they concentrate on discrete knowledge and facts about English and have neglected the practice of teaching. As stated by Zhan (2008), "learning at the university will not automatically transfer to schools in actual teaching practice" (p. 68).

\section{Second: Importance of the In-Service Programs}

An in-service training program includes activities that prepare teachers to become professionals in the field of teaching English. Such a program is proposed for teachers working in schools to improve their performance (Sapp, 1996). He and Yan (2011), "Despite the frequent criticism directed toward them, in-service teacher training (INSET) programs remain one of the most commonly used approaches for enhancing teachers' professional development" (p. 553).

Most student teachers claim that after they graduate and become teachers in public schools, they will not need

$$
\text { مجلة كلية التربية- جامعة عين شمس } 21 \text { () العدد الأربعون (الجزء الرابع) } 2016
$$


any continuing education. The Ministry of Education has a responsibility to provide some in-service educational training programs for its teachers to catch them up with new trends in English language teaching. Some studies have highlighted the positive effects of such programs. Al Malihi (2015) indicated that, "training programs are essential in providing teachers with professional skills to keep them up-to-date concerning teaching methodology" (p. 88). These in-service training programs should have goals that teachers need to achieve. Teachers should be introduced to new trends and methods in language teaching while learning new skills they might not have developed during their pr-eservice training.

Other studies, like Chou's (2008), observed and interviewed elementary school English teachers and found that a good in-service training program will produce an effective EFL context. Also, Zuheer (2013) found that teachers who attended service-week training programs have achieved the main goal of the program, which was developing the way they teach in class. He attributed this success to the teachers themselves because they played a major role during the program to develop their skills in class. He found out that when teachers collaborated and exchanged their experiences during the in-service program, their performance improved. Other studies tried to investigate the needs of English teachers. Iqawa (2008) pointed that the 44 in-service teachers whom he surveyed in his study, indicated they need more training in "teaching skills and methods" more than the other skills he mentioned in his study. Kavak, N., Yamaka, S., Bilici, S., Bozukurt, E., Darici, O. \& Ozakaya, Y. (2012) found that the participants in the study were satisfied with the in-service teacher training program and had positive attitudes about it. However, they suggested

$$
\text { مجلة كلية التربية- جامعة عين شمس } 22 \text { () العدد الأربعون (الجزء الرابع) } 2016
$$


that such a program should be administered within the school environment by professionals or expert teachers.

In fields other than English teaching, in-service training programs have proven to be successful in the eyes of the participants. Gonen and Kocakaya (2005) found that physics teachers believe that in-service training is essential for their professional improvement. Aydin (2008) checked teachers' perception of in-service training and their administrators' support and found significant differences in the use of knowledge and skill levels in schools and their personal character.

\section{Third: Pre-service and In-Service Training for English as} a Second Language Teachers in Developed Countries

The most important countries in which Saudi students have scholarships to study for their undergraduate or postgraduate programs are the United States and United Kingdom. Therefore, this paper will focus on the preparation of English as a second language (ESL) and English as a foreign language (EFL) teachers in these countries. In the United States, there are some qualifications and conditions that must be met before the applicant can teach in public schools. In fact, most public schools require specific academic degrees that enable a person to be eligible to teach. A 1971 statement of qualifications and guidelines for the preparation of ESL teachers in the United States stated that:

"The preparation of a teacher in this country usually consists of: general education, courses and experiences which help him become a well-educated person; academic specialization, courses and experiences which help him become proficient in an area of concentration; and professional education, experiences which help him prepare himself as an educator." (Teachers of English to

$$
\text { مجلة كلية التربية- جامعة عين شمس } 23 \text { () العدد الأربعون (الجزء الرابع) } 2016
$$


An EFL In-service Training Program for Developing EFL

Teachers' Perofrmance

Speakers of Other Languages Institute, 1971,

p. 3)

The statement (Teachers of English to Speakers of Other Languages Institute, 1971) identified that these requirements follow the presupposed competition of the baccalaureate degree. In addition, one Wikipedia article (2016) explains that all teachers in the United States must hold a minimum of a bachelor's degree with a major in a certified area (English or language arts, science, fine arts, math, etc.). Moreover, all teachers in the United States must have appropriate training and pass standardized tests such as state or national level exams. Samson and Collins (2012) noted, "Clearly, teachers of ELL students need the appropriate training to be able to meet their students' language and learning needs and to facilitate academic growth, yet most teachers lack this training" (p. 8). Moreover, they add that "in most states, teacher certification includes completion of a teacherpreparation program and achieving scores on the state's teacher examination." (p. 13). In the United States, most of the colleges that have teacher preparation programs place great emphasis on specializing teachers for every stage of public school. They offer programs to prepare primary school teachers and programs to prepare secondary school teachers. For each of these programs, prospective teachers must complete the requirements of a Bachelor of Arts (BA) degree in addition to a fifth year internship to ensure that they will progress in their teaching career.

In the United Kingdom, teachers must have a qualified teacher status, which can be obtained in many ways. The first is to earn an undergraduate degree, such as a $\mathrm{BA}$ or Bachelor of Science, then get a postgraduate certificate in education. The second is having a specific teaching degree or getting special training on-the-job. The

$$
\text { مجلة كلية التربية- جامعة عين شمس } 24 \text { () العدد الأربعون (الجزء الرابع) } 2016
$$


third is to pass a statuary one-year induction to be certified as a teacher (Wikipedia, 2016).

\section{Methodology of the Study}

\section{Participants}

The participants of the study were all the 50 English language teachers (male) in public high schools of Al-Kharj province, Saudi Arabia. In addition, all thirteen teachers in private high schools received the same questionnaire.

\section{Instrument}

The questionnaire consisted of two main parts. A letter to the participants (appendix A) and the qualitative information questionnaire which included 28 items that covered five main themes (see: appendix B). These themes were personal information, the amount of training they had, their current teaching practices, development and training courses they took pre or in-service, and their impression of their pre and in-service preparation.

\section{Data Analysis}

The data gathered was thoroughly analyzed and discussed. There were 50 distributed questionnaires, 35 only returned. Out of the 35 participants, there were 13 teachers, who were not Saudis, received the questionnaires from the administration of education directly, but were excluded. This study concentrates on Saudi teachers. Also, two questionnaires by Saudis were excluded because they did not complete the questionnaire. Thus, only 19 teachers responded.

Personal information. Four questions were presented in this section. On the first question, the name of the institution, most of the participants responded that they had earned their degrees from King Saud University (KSU: 15 teachers). However, it should be clarified that when a participant point that he graduated from King Saud and

$$
\text { مجلة كلية التربية- جامعة عين شمس } 25 \text { () العدد الأربعون (الجزء الرابع) } 2016
$$


An EFL In-service Training Program for Developing EFL

Teachers' Perofrmance

selected a (literature) on question number 2, this means he graduated from the college of arts. If he chose KSU and selected $b$ (education), this means he graduated from the teachers college. Finally, if he selected choice c (general) from question 2 , then he graduated from the language and translation college. Hence, among those who replied, 17 teachers $(90 \%)$ held a BA in English, one $(5 \%)$ earned a BA in English and a postgraduate diploma in education, and one (5\%) held a Master of Arts (MA) in applied linguistics. The teaching experience of the teachers who participated in the study varied. Three teachers (16\%) had 1-2 years of experience teaching English at Saudi Public high schools in Al-Kharj Province, two (11\%) had 3-5 years, 10 (52\%) had 6-10 years, and four (21\%) had more than 10 years of experience.

Amount of training. Ten teachers (52\%) indicated that they studied 1-2 methodology courses during their undergraduate programs, two (11\%) studied 3-4, four (21\%) studied 5-6, and three (16\%) studied more than seven. However, when they were asked whether they studied specific courses about language skills, their answers varied. As for studying specific courses on how to teach writing composition, four teachers $(21 \%)$ responded by yes and 15 (79\%) responded by no. For reading skills, five teachers $(26 \%)$ retorted by saying they had taken a specific course, whereas the remaining 14 teachers (74\%) answered by saying they did not take a specific reading skills course. When participants were asked whether they had any specific courses on how to teach listening and speaking skills, seven teachers $(37 \%)$ responded by yes, whereas the remaining 12 $(63 \%)$ responded by no. For general courses in English (applied linguistics), 10 teachers (53\%) they studied the subject, whereas seven (47\%) replied that they had not

$$
\text { مجلة كلية التربية- جامعة عين شمس } 26 \text { () العدد الأربعون (الجزء الرابع) } 2016
$$


studied these subjects. Teachers were also asked whether they had any specific courses on the teaching of English during their undergraduate studies. Eight teachers (42\%) answered they had, and 11 teachers (58\%) answered they had not.

Current teaching practice. In this section of the questionnaire, teachers were given indirect questions to test whether they used some important teaching strategies in their classrooms. First, they were asked about the number of periods allocated for writing compositions in their classrooms. Their replies were as follows. Three teachers (16\%) said they did not allocate any periods, 13 teachers $(68 \%)$ allocated only one, two teachers (11\%) allocated two, and finally, one teacher (5\%) allocated three. When they were asked whether they paid attention to the three stages of the composing process when they taught writing, 11 teachers (58\%) said they did, while eight teachers (42\%) said they did not. Participants were also asked how many periods they allocated to reading in their classes. Their answers were as follows: two teachers $(11 \%)$ answered they did not allocate any specific period, 10 (53\%) answered they allocated one period, three $(16 \%)$ answered they allocated two periods, one $(5 \%)$ responded he allocated three periods, two (11\%) responded they allocated four periods, and one (5\%) responded he allocated 5 periods. When teachers were asked whether they had determined the readability level of textbooks before using them, six teachers $(32 \%)$ determined the readability, while $13(68 \%)$ did not determine the readability. Teachers were asked how many periods they set aside for listening and speaking in their classes. Their answers varied: two teachers (11\%) said they did not allocate any periods, $12(63 \%)$ said they allocated one, four $(21 \%)$ said they allocated two, and one (5\%) allocated three. The question on the number of periods allocated for listening and

$$
\text { مجلة كلية التربية- جامعة عين شمس } 27 \text { () العدد الأربعون (الجزء الرابع) } 2016
$$


An EFL In-service Training Program for Developing EFL

Teachers' Perofrmance

speaking skills was followed up with three yes or no questions regarding the types of activities that the teachers practiced. For oral presentation activities, 12 teachers (63\%) replied that they asked students to do them, while seven teachers $(37 \%)$ replied by saying they did not. 13 teachers $(68 \%)$ said they used roleplaying while reading books in class, while six (32\%) said they did not. Regarding the third item, organizing symposia and debates, only seven teachers (37\%) said they did this activity, while 12 teachers $(63 \%)$ said they did not.

Developing and training courses. In this section, very important questions were asked to the teachers to determine whether they had enough training as English language teachers. It was found that during the 12 months since the questionnaire was distributed, nine teachers (47\%) did not attend any of the in-service training programs conducted by the Ministry of Education. While, nine teachers $(47 \%)$ indicated that they attended 1-2 training programs. One teacher $(6 \%)$ exposed that he attended more than (2-4) programs. When the teachers were asked about the value of these training programs, seven $(37 \%)$ pointed that the programs had no value, seven $(37 \%)$ reported that they had little value, four $(21 \%)$ said they had some value, and one teacher $(5 \%)$ said they were highly valuable. Another important question that was asked was whether they attended the workshops their universities offered them to develop themselves in the last 12 months, and 13 teachers (69\%) said they did not attend any of them. The remaining six teachers (31\%) said they attended 1-2 workshops. When they were asked about the value of these workshops, their replies varied. Eight teachers (42\%) replied that these workshops had no value, six $(26 \%)$ replied that they had little value, three $(21 \%)$ asnwere they had some value, and two (11\%)

$$
\text { مجلة كلية التربية- جامعة عين شمس } 28 \text { () العدد الأربعون (الجزء الرابع) } 2016
$$


said they had great value. Another question used to measure the teachers' interest in developing themselves was whether they were members of any professional associations of English teachers in the Kingdom of Saudi Arabia or abroad. Their answered were very clear that none said yes which means (0\%), while $100 \%$ of the paricipants said no. Accordingly, they gave no names of professional associations when asked. Additionally, the teachers' replies to the next question, which was to list some of the names of professional journals they subscribed to, read regularly, or read occasionally, was as follows: One teacher (5\%) read English Language Teaching Journal, six (31\%) read it occasionally, and 11 teachers $(68 \%)$ did not select any of the choices. Only four teachers (26\%) read TESOL Quarterly occasionally, while the remaining 15 teachers $(74 \%)$ selected none of the choices. Finally, they were asked to name any other journals, and none did.

\section{Participants General Impression}

The teachers' answers to the question regarding how satisfied they were with their undergraduate preparation showed that five teachers $(26 \%)$ were satisfied, 12 teachers $(53 \%)$ were dissatisfied, and two teachers $(11 \%)$ were very dissatisfied. The second question in this section asked them to indicate areas in which they would like more training in order of importance. The results were as follows: $84 \%$ of responses wanted more training on English teaching strategies in general ( $\mathrm{D}$ in the questionnaire). $57 \%$ of the participants need to have applied linguistic courses (E), $42 \%$ need to have more training on teaching listening and speaking skills (B), $31 \%$ need to be trained on teaching reading skills (C), and $39 \%$ wanted more training on teaching writing skills (A). The responses to the question about what influenced how the teachers taught were as follows: five teachers $(26 \%)$ said that it was their training

$$
\text { مجلة كلية التربية- جامعة عين شمس } 29 \text { () العدد الأربعون (الجزء الرابع) } 2016
$$


An EFL In-service Training Program for Developing EFL

Teachers' Perofrmance

program, 10 teachers (52\%) said that it was their own English teachers, two teachers $(11 \%)$ said indicated that it was the books provided by the school, and two (11\%) said it was their own experience. Teachers' impressions of their teaching styles varied. Six teachers $(31 \%)$ said they stuck to the teacher's book instructions only (syllabus), four (21\%) said they were very creative, six (37\%) said they did more than what the subject required, and three (16\%) said they only taught what the subject required. All teachers (100\%) believed that there was a big gap between theory and practice in terms of how English was actually taught in their schools.

\section{Data Discussion}

The personal information gathered for this research revealed that most of the teachers in public high schools are graduates of arts colleges, which means that they did not have enough training to teach English. This is clear because 11 teachers graduated from literature programs, five from education programs, two from general English programs, and only one from the MA program in applied linguistics. This also shows that most English teachers in Saudi public schools hold only a BA degree, and the Ministry of Education does not require any training beyond the degree. In fact, this is not good compared to the requirements of teachers in developed countries, as mentioned in the literature review. In addition, the participants' personal data proves that most of them had enough experience to judge the situation of English teaching in Saudi Schools, as more than 14 of them had over six years of experience.

The analysis of the questionnaire presented that most of the English language teachers in Saudi high schools are not well prepared. This was clear because most of the teachers in this study reported that they had only one or two

$$
\text { مجلة كلية التربية- جامعة عين شمس } 30 \text { () العدد الأربعون (الجزء الرابع) } 2016
$$


methodology course during their four year BA programs. However, they have enough knowledge of English because of the excess English courses they studied.

One of the participant teachers stated that, "during my four years study in college of Arts, I do not remember that we had more than one course on how to teach English." $\mathrm{He}$ added, "In our college there is no internship nor practicum". Another teacher reported that, "when I first employed by the ministry to be a teacher, I had no idea how I am going to teach, but I used teachers book and some ready prepared teacher's syllabus to teach the first class."

Only teachers who graduated from the Faculty of Education showed that they had more than seven methodology courses which include (how to teach speaking, how to teach writing, how to teach listening, how to teach reading, general teaching methods, theories of language teaching, and finally using modern technology in teaching) . However, such teachers are not the majority in Saudi schools. Of course, a lack of methodology courses resulted in the existence of fewer courses on how to teach language skills. However, most of the teachers studied one general course, introduction to applied linguistics, as undergraduates, but this is not enough to prepare them to teach language skills appropriately. It is also clear that most of the teachers have taken one or more courses on how to teach English, but not enough to make ready to teach English in public high schools.

One teacher said, "I remember I studied two credit hour course on the second semester on methodology of language teaching, then on the even semester I studied another course on teaching, and lastly we went for a practicum but that was only two hours of teaching per week which in my opinion was not enough."

العدد الأربعون (الجزء الرابع) 2016

مجلة كلية التربية- جامعة عين شمس 31 () 
An EFL In-service Training Program for Developing EFL

Teachers' Perofrmance

Unfortunately, the teachers' responses to the questions related to their current experiences indicated and confirmed that they did not have enough training on how to use language teaching strategies to teach each of the language skills. One teacher responded, "I do not think that 4 credits on how to teach English in our undergraduate years will be enough for us to be well prepared." "However teachers cannot be blamed for not allocating enough time or class periods to teaching language skills for a few reasons. First, the book they use does not allocate how much time each periods for each skill. Second, each period is a 45 minute class, which is not enough time to apply more than one or two teaching strategies. Third, there is a large number of students in each class, which does not give the teachers a chance to use their strategies because they have to cover the whole syllabus before the end of the semester. One teacher addressed a question to the research by saying "do you think a 45 minutes is enough to allocate time to teach the subskills of English or do you think that we are allowed to deviate from the curriculum given to us?"

The teachers who said they allocated two or more periods may have had few students in their classes that gave them time to apply some of the strategies mentioned in the questionnaire. However, when teaching listening and speaking, teachers found that students enjoyed making noise and having fun and therefore were encouraged to participate. This is why most of the teachers' responses showed that they used oral presentations and roleplaying as major activities.

The main objective of the research was achieved in this section of the questionnaire, which revealed how much the teachers trained to prepare themselves to teach English. The responses were very disappointing. From the 19 teachers, nine $(47 \%)$ said they did not have an in-service

$$
\text { مجلة كلية التربية- جامعة عين شمس } 32 \text { () العدد الأربعون (الجزء الرابع) } 2016
$$


program. The reasons were as follows: First, most of the teachers in our public schools teach 24 periods of 45 minutes each, which gives them no time to attend training programs. Second, after a hard day, most of them do not like to use their after work time for anything besides correcting their students quizzes, notebooks, and homework and preparing for the next day. Third, teachers are not given time off from work to attend these programs. As one teacher remarked, "I have 34 students in my class, I have 20 periods, I do not have time to spare to go anywhere but to correct homework, prepare for next day, and relax." Another added, "They should give us time off to attend theses training programs."

Nine teachers $(47 \%)$ reported that they attended 1-2 programs, and only one attended more than 2-4 programs. There are some reasons why those teachers were able to attend trainings. First, they were assigned few periods to teach because there were extra teachers in the same school. Second, some of them were expert teachers who did not take much time to prepare for class the next day, which gave them enough time to attend programs. Finally, most of the training programs in the Ministry of Education were presented after school hours. The teachers' opinion of the value of in-service programs was predictable, as most of them did not attend such programs and those who did feel that they were of no value $(37 \%)$ or little value $(37 \%)$. The reason for these responses has to do with the methods and scheduling of these programs

One teacher reported, "When a teacher gets maximum of 16 periods to teach, then I will be able to attend these inservice programs." If a teacher did not attend, he obviously would not find it valuable, but if he attended, then the main purpose would not be the educational benefit but an excuse to take some time off from teaching classes. As one teacher said, "If I attended or did not attend what is the difference? I

$$
\text { مجلة كلية التربية- جامعة عين شمس } 33 \text { () العدد الأربعون (الجزء الرابع) } 2016
$$


attended one program and the trainer was one of our old friends who became a supervisor in the Administration of Education. No experts."

When teachers were asked how many workshops they attended, the majority said none $(69 \%)$ for the same reasons mentioned for the previous question, including busy schedules, a lack of time off, and an unwillingness to work extra hours for training. Similarly, those teachers believed that these workshops were worthless and offered no value. For instance, one teacher said, "workshops are presented by our colleagues who used to be teachers like us. They do not bring people from developed countries like the USA in order to learn new things."

Unfortunately, most of our schools do not have libraries. Thus, teachers-particularly English teachers-do not have the resources to stay up-to-date with what is new in the field. Most of the teachers did not subscribe or become members of any English associations in the Kingdom of Saudi Arabia because they did not know about them, nor they were introduced to the English journals during their undergraduate years. What is worse is that some of them said, "We have no authorized association in Saudi Arabia." Hence, none of the teachers is a member of any of these associations. We should not blame the teachers. Rather, we should blame the Ministry of Education, which does not encourage its teacher to attend conferences, subscribe to journals, or join associations.

Most of the teachers expressed their impressions of their preparatory years in undergraduate programs. The majority of the teachers said they were either dissatisfied or very dissatisfied with their preparation. This is clear to them because they came to know that they should have been prepared in a different way to be good teachers. From

$$
\text { مجلة كلية التربية- جامعة عين شمس } 34 \text { () العدد الأربعون (الجزء الرابع) } 2016
$$


previous parts of the questionnaire, the teachers understood that they missed many things, such as attending in-service programs or workshops or good English teacher programs. The few teachers who showed satisfaction may have developed themselves or attended some in-service programs and workshops.

A teacher noted that, "during my undergraduate years I studied about 6 methodology course which made me know how to deal with my students." Of course, this is true because this particular student graduated from a school of education, which puts more emphasis on methodology than content. However, when it comes to knowledge-based content, one student said, "In the schools of education we concentrate on topics other than pure English." Generally, when they were asked to arrange the areas in which they wanted more training, they prioritized general English teaching strategies. It seemed logical to them to put this choice first because most of them indicated that they lacked many things during their undergraduate years. This was further emphasized when they indicated that the great influences were their English teachers. In other words, they are imitating their own teachers rather than using the knowledge they learned in college. One participant said, "On my first class I tried to imitate the teacher whom I observed for my practicum class who used to be my teacher during the high school."

In contrast, there are two teachers who said they used the information they gained and learned from the training program. Given that the teachers in this study showed that they did not have much training, most of them stuck to a teacher's book for their teaching style. Some who may have attended workshops or in-service programs gave students extra information about English, but they were few. However, all teachers asserted that there was a big gap

$$
\text { مجلة كلية التربية- جامعة عين شمس } 35 \text { () العدد الأربعون (الجزء الرابع) } 2016
$$


between what they studied and what they should practice. Therefore, it was not surprising that all teachers said there was a gap between theory and practice. A teacher noted, "After I reviewed this particular questionnaire, I came to know what I am and what I should be. I think the gap is too big between what we learn and what we do."

\section{Answering the Research Questions}

The first research question is, Have Saudi English teachers been adequately prepared to teach English in general? The answer is no. Most of the participants in this study graduated from The School of Arts that did not concentrate on preparing them to be English teachers. Furthermore, they have not been given enough training to teach language skills, as the majority of them said they did not take specific courses on teaching language skills.

Second, are they adequately prepared to use English language teaching strategies? Based on their responses regarding how many methodology courses they have attended, they are not adequately prepared to use English language teaching strategies. Furthermore, they have each only taken one course on applied linguistics, which is not enough to prepare a teacher to be use general and specific language teaching and learning strategies for each skill. Of course, those teachers who graduated from the school of education said they took more than seven methodology courses, though they lacked the English knowledge component. Therefore, we can conclude that Saudi teachers are not adequately prepared to use English language teaching strategies.

Third, are they adequately prepared to teach English language skills (reading, writing, listening, speaking)? When we compare teachers' responses regarding how many periods they allocated to teaching each individual skill and

$$
\text { مجلة كلية التربية- جامعة عين شنمس } 36 \text { () العدد الأربعون (الجزء الرابع) } 2016
$$


whether they paid attention to the three stages of composing writing, the majority said they did not. The same applies to reading skills, as the teachers did not determine the readability level of their textbooks. When listening and speaking were examined, it was found that the teachers used this skill more than the others did because the activities they used encouraged students to participate. Thus, we can say that teachers' undergraduate educations do not fully prepare them to use different teaching strategies for all language skills. Any student participation during the teaching of listening and speaking skills could be because students like noisy classes. Teachers indicated that this was why they assigned these activities more than the others did.

Fourth, are they aware of applied linguistics courses? Not at all. When looking at their responses, it is clear that the majority said they took one general course on applied linguistics. The rest did not take this course. In addition, most of the teachers were not aware of English language journals that talk about such issues. Most of them did not subscribe to journals. Moreover, they did not know that there was an English language association the Kingdom of Saudi Arabia, from which they could develop their knowledge about current issues in language teaching. Therefore, the answer to this question is no, they are not aware of applied linguistics issues.

Fifth, Do Saudi English teachers need an in-service training program? There is no doubt that Saudi teachers need an in-service training program. From their responses, we notice that the majority either attended no in-service programs or only 1-2 per year. Further, they believed that the programs were not valuable. The case is the same with workshops and seminars - the majority attended none and believed that they were not or barely valuable. Therefore, future and current Saudi teachers need to get more involved

$$
\text { مجلة كلية التربية- جامعة عين شمس } 37 \text { () العدد الأربعون (الجزء الرابع) } 2016
$$


An EFL In-service Training Program for Developing EFL

Teachers' Perofrmance

in such workshops and seminars to develop their teaching skills and strategies.

Sixth, how do schools of education in the United States prepare Saudi students studying there? Saudi students studying in the United States or United Kingdom do so for two or more reasons: to earn a master's or $\mathrm{PhD}$ degree in teaching English as a second language (TESOL), applied linguistics, theoretical linguistics, or literature in general. In the first two majors, students are given enough courses on the methodology of language teaching, strategies of teaching each individual language skill, theories of language acquisition, theories of language teaching, a one or two semester practicum, and an internship of at least one semester in which they are observed by their supervisors. Thus, we can say that a Saudi teacher holding an MA or PhD from a TESOL or applied linguistics programs in the United States are well prepared to be good English teachers. In turn, they are prepared to teach in undergraduate schools.

Seventh, how do schools of education in the United States deliver in-service programs to English teachers? Generally, the U.S. system is almost the same. Most undergraduate students are not prepared to teach upon graduation. This is the case for all majors. When people decide to teach, they must study an extra year in what is called preparation for teachers (as stated in the literature section). Some schools have special programs for each level of public schools. Others require some teaching licenses and certificates. In addition, some states require teaching exams. However, the United Kingdom has different requirements. Teachers there must have a Qualified Teacher Status in order to be English teachers.

Eighth, Are Saudi English teachers aware of the difference between theory and practice? Fortunately, yes.

$$
\text { مجلة كلية التربية- جامعة عين شنمس } 38 \text { () العدد الأربعون (الجزء الرابع) } 2016
$$


Khalid M. Alwahibee

However, they do not demonstrate this through their teaching. As shown by the questionnaire, they just do their jobs by following the instructions given to them by the Ministry of Education. At the same time, the responses reveal that some of the teachers think the little they learned in their undergraduate years is not applicable in class for many reasons. 
An EFL In-service Training Program for Developing EFL

Teachers' Perofrmance

\section{Suggestions and Implications}

Based on the findings of this research, many suggestions and implications can be addressed to the Ministry of Education, schools, and universities.

1. The Ministry of Education must pay attention to the type of teachers they hire to teach English at the high school level.

2. Since the Ministry of Education hires graduates from different schools and majors, it should impose a one-year training program that contains general methodology courses and specific teaching strategies for language skills for those interested in becoming English teachers.

3. The Ministry of Education must impose a teaching exam to make sure that English teaching applicants are aware of different methods and strategies of teaching language skills and determine teachers' English skill levels.

4. The Ministry of Education should make the teaching license as a major requirement for teachers.

5. Follow-up training should be required for the renewal of teaching licenses.

6. Education administrators must pay attention to the load of teaching hours so that they give teachers enough time to attend some in-service programs, workshops, and seminars to develop themselves.

7. English language departments in all universities must review their programs and include requirements for teaching English.

8. A shared committee should be established and include representatives from English departments and the administration of education to review

$$
\text { مجلة كلية التربية- جامعة عين شمس } 40 \text { () العدد الأربعون (الجزء الرابع) } 2016
$$


requirements for preparing student teachers to focus on courses that will develop their knowledge and skills.

9. Schools and colleges should work on developing a shared practicum program that in which different methods and styles of teaching be provided.

10. Educational institutions should work on developing and reviewing current books for high schools to give teachers time and opportunity to use and teach all language skills.

11. Schools and colleges should encourage teachers to be members of local and international English communities as and subscribers to a few English teaching journals so they stay up-to-date with the newest research areas in the field of teaching.

\section{Conclusion}

This research found that English teachers in Saudi high schools are not well prepared to be English language teachers. It indicated that they lack the knowledge of how to teach English language. In addition, it investigated that Saudi universities from which those teachers have graduated, did not provide them enough training to be strong English teachers. Therefore, this research emphasized the fact that Saudi English teachers need to attend in-service training programs to develop their teaching skills and styles. However, the Ministry of Education should provide them with time to attend such programs. Moreover, Saudi teachers need to go to workshops if they have time despite their full schedules at schools. Some suggestions and implications have been presented to both the universities and the Ministry of Education to reform English language programs and hiring procedures,

العدد الأربعون (الجزء الرابع) 2016

مجلة كلية التربية- جامعة عين شمس 41 () 
An EFL In-service Training Program for Developing EFL

Teachers' Perofrmance

\section{References}

Akintola, A. M. (1982). A survey of the preparation of English language teachers in selected secondary schools, Oyo State of Nigeria (Doctoral dissertation, Florida State University). Available from ProQuest Dissertations Publishing. (UMI No. 8229142)

Al-Hazmi, S. (2003). EFL teacher preparation program in Saudi Arabia: Trends and challenges. TESOL Quarterly, 37(2), 341-344.

Al Malihi, J. (2015). Saudi teachers' readiness and perceptions of young learners teaching at elementary schools. English Language Teaching, 8(2), 86-100.

Al-Seghayer, K. (2011). English teaching in Saudi Arabia: Status, issues, and challenges. Riyadh, Saudi Arabia: Hala Print Co.

Aydin, D. (2008). Teachers in-service training programme by yöneticiler supporting education projection. Levels of knowledge and skills acquired as a result of investigation (Master's thesis, Yeditepe University, Istanbul, Turkey).

Chou, C. (2008). Exploring elementary English teachers' practical knowledge: A case study of EFL teachers in Taiwan. Asia Pacific Education Review, 9(4), 529-541.

Freeman, D. (1989). Teacher training, development, and decision making. TESOL Quarterly, 23(1), 27-47.

Freeman, D. (2001). Language teacher education. In R. Carter \& D. Nunan (Eds.), The Cambridge guide to teaching English to speakers of other languages (pp. 72-79). Cambridge, MA: Cambridge University Press.

Gönene, S. \& Kocakaya, S. (2005). The comparison of physics achievements and computer attitudes of the first year students of a high school according to two different instruction methods. Pamukkale Univeristy Journal of education Faculty, 17(1) (pp. 14-22).

Hammadou, J. (2004). Identifying the best foreign language teachers. Teacher Standards and Professional Portfolio, 88(3), 390-402.

$$
\text { مجلة كلية التربية- جامعة عين شنمس } 42 \text { () العدد الأربعون (الجزء الرابع) } 2016
$$


Igawa, K. (2008). Professional needs of EFL teachers Practcing in Japan and Korea. Shiten'no International Budhism's University, 4.4 Retrieved fromHttp://www.shitennoji.ac.jp/ibu/images/toshkoankiya do45-21.pdf।

Johnson, K. E. (Ed.). (2000). Teacher education. Alexandria, VA: Teachers of English to Speakers of Other Languages.

Kazemi, A., \& Ashrafi, M. (2014). In-service training programs for Iranian EFL teachers revisited. International Journal of Asian Social Science, 4(10), 1062-1076.

. Kavak, N., Yamaka, S., Bilici, S., Bozukurt, E., Darici, O. \& Ozakaya, Y. (2012). The evealuation of primaory and secondary teachers' opinionvabout in-service teacher training. $4^{\text {th }}$ World Conference on Educational Sciences (WCES-2012) 02-05. Procedia: Social and Behhavioral Sciences, 46 (pp. 3507-3511).

Lee, I. (2007). Preparing preservice language teachers for reflective practice. ELT Journal, 61(4), 321-329.

Lorite, D. (1975) School teacher: A sociological study. Chicago: University of Chicago Press.

Ministry of Education, P.R.C. (2001). English language curriculum standards. Beijing, China: Beijing.

Rice. J. K. (2003). Teacher quality: Understanding the effectiveness of teacher attributes. Washington, DC: Economic Policy Institute.

Richards, J. C. (1998). Beyond training: Perspective on language teacher education. New York: Cambridge University Press.

Saban, A. (2002). Towards a more intelligent school. Educational Leadership, 60(2), 71-73.

Samson, J. F., \& Collins, B. A. (2012). Preparing all teachers to meet the needs of English language learners: Applying research to policy and practice for teachers' effectiveness. USA: Center for American Progress.

Sapp, T. M. (1996). Teacher perceptions of the components of effective in-service training in the fine arts and their relationship to the implementation of curriculum

$$
\text { مجلة كلية التربية- جامعة عين شمس } 43 \text { () العدد الأربعون (الجزء الرابع) } 2016
$$


An EFL In-service Training Program for Developing EFL

Teachers' Perofrmance

improvement innovations (Unpublished doctoral

dissertation). College of Education, Georgia State University, Atlanta, GA.

Teachers of English to Speakers of Other Languages Institute (1971). Statement of qualifications and guidelines for preparation of teachers of English to speakers of other languages in the United States. USA.

Wikipedia, The Free Encyclopedia (2016) Certified teacher [Article]. Retrieved from https://en.wikipedia.org/w/index.php?title=Certified_Teac her\&oldid $=726081640$.

Wright, S., Horn, S., \& Sanders, W. (1997). Teacher and classroom context effects on student achievement: Implications for teacher evaluation. Journal of Personnel Evaluation in Education, 11, 57-67.

Yan, C., \& He, C. (2011). Enhancing part-time in-service teacher training programmes to facilitate rural teacher development. Prospects, 41, 553-566. doi:10.1007/s11125-011-92-9

Zaid, M. (1993). Comprehensive analysis of the cultural system of teaching English as a foreign language in Saudi Arabian intermediate schools (Unpublished doctoral dissertation). The University of Colorado, Boulder.

Zhan, S. (2008). Changes to a Chinese preservice language teacher education program: Analysis, results and implications. Asia-Pacific Journal of Teacher Education, 36(1), 53-70.

Zuheer, K. (2003). Developing EFL teachers' performance at Sana'a secondary schools in the light of their professional and specialist needs (Doctoral dissertation, Cairo University, Institute of Educational Studies, Cairo, Egypt). Retrieved from http://files.eric.edu.gov/fulltext/ED541645.pdf.

$$
\text { مجلة كلية التربية- جامعة عين شمس } 44 \text { () العدد الأربعون (الجزء الرابع) } 2016
$$




\section{Appendix A}

A Letter to the English Language Teacher

Dear English Language Teacher,

I am Dr. Khalid M. AlWahibee, an associate professor of English language curriculum and instruction. I am working on a research paper on English education in the schools of Al-Kharj Province. Part of my research is to find out whether teachers in selected secondary schools in Al-Kharj Province consider their undergraduate preparation in ESL adequate for their classroom responsibilities.

Therefore, the purpose of this letter is to request that you fill out the attached questionnaire, which asks you specific questions on the preparation you had as an ESL teacher and the various courses that you are now teaching in your classes. The information obtained from you and other teachers in our schools in the Province will enable me to successfully carry out this study.

Thank you for your cooperation.

Yours sincerely,

Dr. Khalid M. AlWahibee

Associate Professor of English Language and instruction Imam Mohammed Bin Saud Islamic University 
An EFL In-service Training Program for Developing EFL

Teachers' Perofrmance

\section{Questionnaire}

\section{Appendix B}

Modified from Akintola, A. M. (1982). A survey of the preparation of English language teachers in selected secondary schools

\section{Part I (Personal Data)}

1. Name of institution at which you earned your first degree (Optional):

2 Your highest degree at present (please check one): (a) BA in English

(b) BA in English and postgraduate diploma in education

3. If your answer is (a), please check one:
(a) Literature
(b) Education
(c) General

4. How many years of teaching experience do you have? (Please check one):
(a) 1-2 years
(b) 3-5 years
(c) 6-10 years
(d) More than 10 years

\section{Part II (Amount of Training)}

5. How many methodology courses did you study as an undergraduate?
(a) $1-2$
(b) $3-4$
(c) 5-6
(d) More than seven

6. During your undergraduate studies, did you take any specific courses on how to teach writing composition?
(a) Yes
(b) No

مجلة كلية التربية- جامعة عين شمس 46 () العدد الأربعون (الجزء الرابع) 2016 
If yes, please specify:

7. During your undergraduate studies, did you take any specific courses on how to teach reading skills?

(a) Yes

(b) No

If yes, please specify:

8. During your undergraduate studies, did you take any specific courses on how to teach listening and speaking skills?

(a) Yes

(b) No

If yes, please specify:

9. During your undergraduate studies, did you take any specific courses in applied linguistics?

(a) Yes

(b) No

If yes, please specify:

10. During your undergraduate studies, did you take any specific courses on teaching English?

(a) Yes

(b) No

مجلة كلية التربية- جامعة عين شمس 47 () العدد الأربعون (الجزء الرابع) 2016 
An EFL In-service Training Program for Developing EFL

Teachers' Perofrmance

If yes, please specify:

\section{Part III (Current Teaching Practice)}

11. How many periods are spent on written composition in your class to give chance for students to practice? - ............ Periods per week.

12. Do you focus on the three stages of the composition process (prewriting, writing, postwriting) when teaching writing to your class?
(a) Yes
(b) No

13. How many periods are allocated to reading in your class? Periods per week.

14. Do you determine the readability level of textbooks before using them?
(a) Yes
(b) No

15. How many periods are allocated to listening and speaking in your class?

- ............. Periods per week.

16. Does your classroom teaching of listening and speaking include any of the following activities?

(a) Oral presentation by the students? Yes No

(b) Role playing of some parts read in books? Yes No

(c) Organizing symposia and debates?

Yes No

$$
\text { مجلة كلية التربية- جامعة عين ثمس } 48 \text { () العدد الأربعون (الجزء الرابع) } 2016
$$




\section{Part IV (Developing and Training Courses)}

17. In the last 12 months, how many in-service training programs conducted by the Ministry of Education did you attend?
(a) None
(b) 1-2
(c) $2-4$
(d) More than four

18. How valuable did you find the Ministry of Education's in-service programs in your performance?
(a) No value
(b) Little value
(c) Some value
(d) Great value

19. In the last 12 months, how many workshops and seminars conducted by universities have you attended in the Kingdom of Saudi Arabia?
(a) None
(b) $1-2$
(c) $2-4$
(d) More than four

20. How valuable did you find the workshops and seminars on your performance in class?
(a) No value
(b) Little value
(c) Some value
(d) Great value

21. Are you a member of any professional associations of English teachers in the Kingdom of Saudi Arabia or abroad?
(a) Yes
(b) No

مجلة كلية التربية- جامعة عين شمس 49 () العدد الأربعون (الجزء الرابع) 2016 
An EFL In-service Training Program for Developing EFL

Teachers' Perofrmance

22. If yes, which association(s) do you belong to?

(a)

(b)

(c)

23. The following are some journals related to the teaching of English as a second language. Check which you subscribe to, read regularly, or read occasionally:

(Read)

Journals

Regularly Occasionally

(a) English Language Teaching Journal

(b) TESOL Quarterly

(c) Others (specify)
(Read)

Subscribe

\section{Part V (Your General Impression)}

24. How satisfied are you with the preparation you received in your undergraduate program in English?
(a) Very satisfied
(b) Satisfied
(c) Dissatisfied
(d) Very dissatisfied

25. If you were to attend in-service training programs, in which of the following areas would you like to receive more instruction? Please, number them according to their importance to you. Notice that 1 refers to most important and 5 refers to least important.

(a) How to teach writing ( )

(b) How to teach listening and speaking ( )

$$
\text { مجلة كلية التربية- جامعة عين شمس } 50 \text { () العدد الأربعون (الجزء الرابع) } 2016
$$


(c) How to teach reading ( )

(d) Strategies for teaching of English in general ( )

(e) Applied linguistics ( )

26. Which of the following has most influenced your teaching of English?

(a) My training program

(b) My own English teachers

(c) The textbooks provided by my school

(d) Other (please specify):

27. Which one of the following teaching strategies do you follow in your classroom?

(a) Stick to the instructions in the teacher's book

(b) Very creative

(c) Offer more than the subject requires

(d) Offer only what the subject requires

28. Do you think that there is a gap between theory, what we are taught about how English is taught, and practice, how English is actually taught in our schools?
(a) Yes
(b) No

العدد الأربعون (الجزء الرابع) 2016

مجلة كلية التربية- جامعة عين شمس 51 () 